\title{
LUKISAN PELEBURAN CINTA YANG EROTIK: Puisi Sufi di antara Estetika dan Etika Cinta Ilahiyah
}

\author{
Abdul Wachid B.S. \\ Dosen Sekolah Tinggi Agama Islam Negeri (STAIN) Purwokerto
}

الملخص

وفي التراث الصوفي أن الخبرات السكرية لدى الصوفيين قد تؤدى الى ظهور

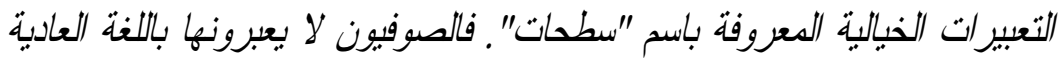

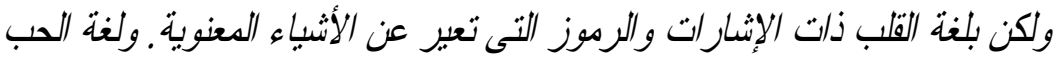

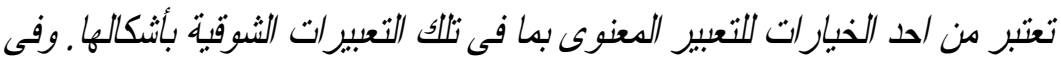

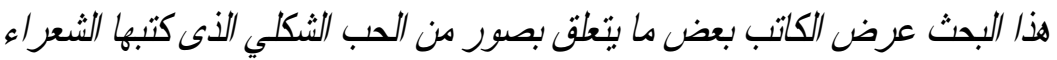

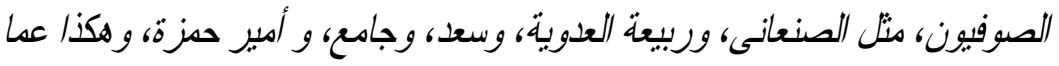
بتعلق بالفلسفة التىى تبنى عليها نلك الكتابات.

\section{Abstract}

The ecstatic experience of a Sufi often drives him or her to producing such unusual sayings ordinarily called as shathiyya, which are some times problematic for common people. This is due to the fact that the expressions are not in common language; they are articulated in "the language of heart", which is figurative and symbolic, since they state conative experiences. In this regard, love poems with their erotic expressions are chosen as a media for a Sufi's reflection. In addition, the writer discusses the rationale of Sufis in connection with their erotic-love poetic illustrations. Some poems of Sufi Poets, such as those of Sana'i, Rabi'a al-Adawiyya, Sa'di, Jämi', 
Abdul Wachid B.S.

and Amir Hamzah, are elaborated for a further appreciation of the Sufis' shațịiyya.

Keywords: shathiyya, cinta, shawq, ma'rifa, mushähada.

\section{A. Pengantar: Shathiyyah, "Pengalaman Cinta", dan Puisi}

Tentang pemahaman cinta seorang sufi kepada Tuhan, ada kesejajaran pandangan Ruzbihan Baqli dan Ja'far al-Shidiq bahwa pada saat hubungan seorang sufi dan Tuhan di dalam pengalaman mistik, pada saat itulah seorang sufi mengalami ekstase spiritual yang memunculkan ungkapan-ungkapan eskatis (shathịyyah), seperti pernyataan Abū Yazid, "Mahasuci Aku" (subhạnīi), atau ungkapan alHallāj, "Akulah Kebenaran" (ana al-Haqq).

Shathiyyah merupakan suatu bentuk pengalaman keruhanian seorang sufi yang telah wajd, yaitu seorang yang telah mencapai ekstase mistik dalam peringkatnya yang tinggi. Keadaan-keadaan ruhani (aḥwāl) yang dicapainya memberi peluang kepadanya untuk menangkap suara yang timbul dari kedalaman pengalaman kalbunya berupa ucapanucapan yang dalam. Contoh dari pengalaman shat"hiyyah itu diungkapkan oleh Ja'făr al-Ṣiddiq, ${ }^{1}$ sebagaimana pengalaman ketuhanan yang dialami oleh Nabi Musa AS di Lembah Tuwā. Dalam peristiwa itu, Musa melihat semak terbakar, lalu mendapat perintah dari Tuhan agar melepaskan kedua alas kakinya.

Pengalaman keruhanian seperti yang dialami Musa itu dapat mengakibatkan seseorang mendapatkan kashf dan kalbunya terisi pengetahuan ketuhanan. Dalam perkembangannya, pengalaman shathiyyah itu berubah menjadi "pengalaman cinta" sebab semakin dekat seorang sufi terhadap Tuhan, karenanya semakin bertambah cintanya kepada Tuhan. Dalam keadaan demikian, ungkapan bahasa menjadi bahasa cinta, bukan bahasa biasa, melainkan bahasa simbolik puisi yang dapat mengungkapkan sekaligus menandai dekatnya hubungan seorang sufi dengan Tuhannya. Hal itu disebabkan bahwa pengalaman shathiyyah merupakan pengalaman kalbu, karenanya membutuhkan

${ }^{1}$ Baldick via Abdul Hadi W.M., Tasawnf yang Tertindas (Jakarta: Paramadina, 2001), hlm. 38 . 
bahasa kalbu pula untuk mewadahinya. Bahasa kalbu tidak bersifat deskriptif, melainkan bersifat figuratif yakni melalui bahasa puisi

Pengalaman shatbiyyah itu pada tingkat umum dapat disamakan dengan pengalaman religius, yang kenyataannya tidak pernah bisa ditunjuk secara langsung sebab bukan pengalaman inderawi. Sementara itu, bahasa memiliki keterbatasan, hanya mengungkap apa yang menjadi realitas inderawi. Karenanya, ada realitas yang dapat disentuh melalui bahasa, dan ada yang tidak (the unutterable). Oleh sebab itu, bahasa religius mempunyai logika tersendiri yakni bersifat analogi, sebagian sama dan sebagian berbeda dengan bahasa dan situasi manusia seharihari. Pengalaman religius itu bersifat konatif, yakni pengalaman yang dialami secara langsung antara subjek dan objek, berlangsung dalam taraf tak sadar, karenanya berlangsung tanpa bahasa. Namun, di saat subjek membahasakan pengalaman religiusnya, maka aspek konatif itu masuk ke aspek reflektif, yakni pengalaman religius yang telah terabstraksikan ke pola inderawi. Perpindahan ini dalam bahasa religius berlangsung dengan jalan analogi, melalui bahasa puisi. ${ }^{2}$

Oleh sebab itu, tiada pengalaman religius yang dapat diungkapkan selain melalui bahasa puisi atau setidaknya bahasa simbolik. Demikian pula halnya dengan pengalaman shathiyyah yang dialami oleh para sufi, yang pencapaian keadaan ruhani ( $a$ hwwād) tersebut memberi peluang kepadanya untuk menangkap suara yag timbul dari kedalaman kalbunya berupa "ucapan-ucapan yang dalam".

\section{B. Penggambaran Cinta Erotik}

Bagaimana percintaan mistik itu diungkapkan melalui "ucapan yang dalam" atau ungkapan eskatis oleh para sufi? Pada dasarnya ungkapan-ungkapan eskatis itu terekspresikan melalui bentuk-bentuk majas atau analogi-analogi. Mengapa hal tersebut demikian? Ibnu 'Arabi menjawab bahwa "Ahli ma'rifah tidak dapat menyampaikan perasaan mereka kepada orang lain, mereka hanya dapat menyatakannya secara simbolik kepada mereka yang memiliki pengalaman serupa." Kenyataan bahwa pengalaman religius itu selalu memerlukan bahasa

${ }^{2}$ Abdul Wachid B.S., Religiositas Alam: dari Surealisme ke Spiritualisme D. Zawawi Imron (Yogyakarta: Gama Media, 2002), hlm. 172. 
simbolik juga digunakan di dalam al-Qur'an. Menurut Muhammad Iqbal, al-Qur'an menggunakan bahasa figuratif atau majas tatkala mengungkapkan pengalaman Nabi Muhammad saw. ketika beliau mi'raj ke langit lapis tujuh dan berdialog dengan Tuhan di Sidrat al-Muntaha. ${ }^{3}$ Banyak sekali ungkapan al-Qur'an yang figuratif atau majas di saat menyatakan pengalaman ketuhanan, seperti dalam surat al-Nūr (24:35):

Allah adalah sumber cahaya langit dan bumi

Perumpamaan cahaya-Nya seperti bejana yang tidak tembus, di dalamnya ada pelita:

pelita itu yang tertanam dalam kaca;

kaca itu bersinar bagaikan bintang cemerlang yang menyala karena minyak zaitun yang penuh berkah

yang tidak di timur dan tidak pula di barat minyaknya bercahaya sendiri meski tak tersentuh api Cahaya berselaput cahaya Allah memberikan petunjuk dengan cahaya-Nya kepada orang yang Ia kehendaki Demikian Ia membuat perumpamaan bagi manusia Allah Mahatahu akan segala hal.

Di dalam puisi yang ditulis para sufi, majas serupa itu menandai kedekatan hubungan antara manusia dengan penciptanya. Majas-majas tersebut sangatlah beragam. Sekalipun demikian, menurut Abdul Hadi W.M. bahwa semua pencapaian keindahan itu berkisar kepada keindahan Yang Satu, kehadiran spiritual-Nya dalam objek yang beraneka-ragam di alam shabādah dan afinitas rahasia-Nya dalam jiwa manusia. ${ }^{4}$ Hal ini didasarkan pada pernyataan al-Qur'an bahwa Yang Satu menghadirkan Diri secara rahasia dalam berbagai tingkat "wujud", sebab Dia adalah “Yang Lahir dan Yang Batin' (QS.57:3), dan "Ayatayat-Nya terbentang di alam semesta dan di dalam diri manusia" (QS. 41:53), karenanya, "Kemana pun kau memandang akan terlihat wajahNya” (QS. 2:115).

Di sinilah pentingnya puisi di saat meneliti pandangan sufisme sebab puisi menjadi media ekspresi terpenting bagi sufi dalam

\footnotetext{
${ }^{3}$ Via Abdul Hadi W.M., Tasawnf, hlm. 38.

${ }^{4}$ Ibid., hlm. 67.
} 
menyampaikan pengalaman cinta ilahiahnya. Menurut Seyyed Hossein Nasr, ${ }^{5}$ para sufi meyakini bahwa kekuatan bahasa puisi dapat membawa seseorang menuju alam hakikat atau mengalami penyatuan mistik dengan Tuhan.

Memang, mengalami penyatuan mistik dengan Tuhan inilah yang menjadi tujuan utama dari ritual hidup para sufi, dan puisi menjadi bagian dari ritus itu. Kemabukan mistikal itu dicarikan tamsilnya kepada taman-taman, kebun, istana, pasar, atau kedai tempat minuman anggur yang menyebabkan kemabukan ruhani terhadap Yang Mahakekasih, semua itu demi mencitrakan keadaan kalbu dan pengalaman ruhani seorang ahli ma'rifah. Sebagian tamsil itu dapat dicarikan rujukannya di dalam al-Qur'an, sebagaimana penggunaan tamsil taman firdausi bahwa seorang ahli ma'rifah itu tingkatannya ibarat berada di "Surga yang terbentang di antara langit dan bumi”" (QS. 3:133).

Menurut Abdul Hadi W.M., maksud penggunaan tamsil taman ini untuk menjelaskan fungsi puisi bagi penempuh jalan tasawuf, "Seperti halnya taman istana dan kalbu orang arif, puisi sebagai hasil perenungan dan makrifat merupakan tempat mengingat (dhikr), memikir (fikr) dan merenung (mushähadah) wajah Kekasih Yang Mahaindah". ${ }^{6}$

Di samping tamsil yang telah disebutkan, ada tamsil lain yang sangat dominan di dalam puisi yang ditulis oleh para sufi, yakni cinta mistik itu diungkapkan dengan pencitraan cinta yang erotik, meminjam istilah Erich Fromm, ${ }^{7}$ yakni pencitraan cinta hubungan lelaki dan perempuan (yang profan). Pencitraan cinta erotik itu dijadikan penanda kemabukan mistik. Oleh sebab para sufi itu kebanyakan kaum lelaki, maka pencitraan erotik yang digunakan ialah kemabukan terhadap perempuan. Demikian halnya, al-Nizāàīi mencitrakan pesona Laylāa yang menggilakan cinta si Qais; Jami mencitrakan pesona Zulaykhā' yang menjadikan Yusuf merasa takjub; Farìd al-Din Attār mencitrakan kecantikan seorang wanita Nasrani yang menjadikan Shaykh Șan'ān tergila-gila dan meninggalkan para santrinya; Ibnu 'Arabi mencitrakan pesona seorang wanita Persia bernama Nizam yang dijumpainya di

${ }^{5}$ Seyyed Hossein Nasr, Knowledge and the Sacred (New York: The Crossroad Publishing Company, 1981), hlm. 271.

${ }^{6}$ Abdul Hadi W.M., Tasawnf, hlm. 69.

${ }^{7}$ Erich Fromm, The Art of Loving (Jakarta : Fresh Book, 2002), hlm. 89. 
sekitar Ka'bah, dan membuatnya mengalami "Mi'raj" sampai berulangulang; demikian halnya dalam puisi yang ditulis oleh Jalāl al-Din Rūmi, Manșūr al-Hallāj, Omar Khayam, Abū Nuwās, dan lainnya. Bahkan, seorang penyair Jerman, Johann Wolfgang von Goethe (1749-1832) juga mengungkapkan pesona tujuh wanita, yang begitu kuat mengubah nasib pasangan-pasangan mereka, yakni Rudaba, Zulaikha, Sirin, Layla, Butsayna, Bilqis, dan 'Azra. Semua itu oleh penyairnya, yang juga seorang sufi, ditulis di dalam bahasa puisi yang begitu memukau.

Sekalipun demikian, ada juga pengalaman mistik yang diungkapkan dengan pencitraan kemabukan terhadap seorang lelaki, sebagaimana dalam puisi yang ditulis oleh wanita sufi penyair, Rabíah al-Adawiyyah. Namun, pada intinya semua pencitraan cinta erotik itu bermaksud sama yakni dijadikan penanda dari pengalaman mistik, suatu upaya untuk mengkonkretkan pengalaman mistik yang semula abstrak itu ke dalam suatu pencitraan yang konkret, yang bisa menyentuh indra kemanusiaan kita. Dengan begitu, gambaran dari birahi cinta (maḥabbab) dan kerinduan (shawq) seorang sufi kepada Tuhannya akan dapat dibayangkan, dirasakan dan dipikirkan oleh pembacanya, yang boleh jadi adalah para muridnya, maupun pembaca lain.

Pencitraan cinta erotik lelaki dan perempuan itu dapat dikatakan sebagai pencitraan dari penyatuan cinta yang paling maksimal sebab tidak hanya secara batiniah, melainkan ada keterwakilan dari penyatuan itu yakni melalui hubungan tubuh. Dari itu cinta erotik menandai (ditandai) sebagai adanya kemabukan yang paling kepayang dari hubungan antara lelaki dan perempuan, yang masing-masing sebagai subjek sekaligus sebagai objek bagi pasangannya. Bahkan, pencitraan cinta erotik ini dapat dikatakan lebih mewakili kemabukan mistik dibanding pencitraan minum anggur sebab kemabukan yang disebabkan minum anggur itu hanyalah sesaat, "lupa diri" sesaat. Namun, kemabukan cinta erotik tidak pernah berhenti sekalipun telah terjadi penyatuan antara diri dengan sang Kekasih. Hal itu seperti kemabukan seorang pria terhadap kekasih sejatinya yang tidak pernah berhenti untuk berupaya melakukan kedekatan. Sekalipun penyatuan tubuh itu telah berlangsung, justru dari situlah sesungguhnya perjalanan cinta baru dimulai menuju hakikat cinta sejati yang maknawiyah. 
Pemakaian citra simbolik erotik dalam puisi karya sufi ini, menurut Abdul Hadi W.M., dapat dimaklumi sebab mereka berbicara tentang cinta sejati itu, dan sasaran cinta mereka adalah Dia Yang Mahaindah. Untuk sekadar contoh, "pelukan" dan "ciuman" digunakan sebagai simbol pesona cinta; "tidur" seperti banyak kita jumpai dalam puisi karya Jalāl al-Dīn Rūmî, dimaksudkan sebagai tafakur, yang makna spiritualnya ialah "tidur terhadap dunia, tetapi bangun memandang Kekasih". Semantara itu, mengapa para sufi menggunakan citra-citra simbolik yang erotik? Alasan Abdul Hadi W.M., berikut ini baru sampai pada tataran estetik, dan efeknya bagi kejiwaan pembaca.

Pertama, dengan menggunakan citra-citra simbolik yang erotik mereka dapat memberi ungkapan puitik halus dan penuh nuansa estetik tentang Keesaan Tuhan; kedua, citra-citra simbolik dan metaforametafora yang demikian mudah meresap ke dalam hati pembaca dan meninggalkan kesan yang dalam dibandingkan dengan menggunakan istilah-istilah falsafah sebab sifat-sifat dan keagungan Tuhan dapat tergambar secara langsung; ketiga, dengan menggunakan citra-citra simbolik erotik, para sufi dapat melindungi rahasia perjalanan ruhani mereka dari pengetahuan orang biasa, dan dengan demikian hanya golongan muntabi dan arif saja dapat mengetahui maknanya. ${ }^{8}$

Alasan pemikiran senada juga diungkapkan oleh Annemarie Schimel dalam "Unsur-unsur Kewanitaan dalam Tasawuf", yang merupakan lampiran dari bukunya yang paling banyak dirujuk pengkaji tasawuf, Dimensi Mistik dalam Islam. ${ }^{9}$

\section{Filosofis Penggambaran Cinta Erotik}

Namun di segi lain, landasan filosofis apa yang menjadikan pemikiran dan pengalaman mistik para sufi itu justru dicarikan medianya melalui pencitraan cinta erotik di dalam puisinya?

Pertama, sebagaimana sudah diungkapkan di depan bahwa pencitraan cinta erotik itu sebagai media yang paling mewakili ekspresi kerinduan (shawq) seorang sufi terhadap Tuhan, yang di dalam puisinya

${ }^{8}$ Abdul Hadi W.M., Tasawnf, hlm. 93-94.

${ }^{9}$ Annemarie Schimmel, Dimensi Mistik dalam Islam, cet. II (Jakarta: Pustaka Firdaus, 2003), hlm. 542-557. 
selalu disebut sebagai "Kekasih" atau nama-nama perempuan. Ungkapan kerinduan ini bukan hanya dari sudut-pandang seorang manusia terhadap Tuhannya, melainkan kerinduan timbal-balik bahwa Tuhan juga sangat merindukan hamba-Nya : "Dia mencintai mereka dan mereka mencintai-Nya" (QS. al-Mà'idah, 5:54). Karenanya, hal itu ditamsilkan dalam sebuah hadis qudsi bahwa jika ada seorang hamba yang mendatangi-Nya dengan berjalan, maka Allah akan menyambutnya dengan berlari, selengkapnya berikut ini :

"Aku memenuhi harapan-Ku tentang diri-Ku, dan Aku bersamanya ketika dia ingat (atau memohon) kepada-Ku. Jika dia mengingat-Ku di dalam hatinya, Aku mengingatnya di dalam hati-Ku; dan jika dia mengingat-Ku secara terbuka, Aku mengingatnya secara terbuka yang jauh lebih baik daripada itu. Dan jika dia mendekati Aku sehasta tangan, Aku akan mendekatinya sedepa; dan jika dia mendekati-Ku sedepa, Aku akan lebih dekat lagi; dan jika dia mendekatiku dengan berjalan, Aku akan mendatanginya dengan berlari". ${ }^{10}$

Dengan begitu, hubungan cinta menjadi saling berbalas sehingga mengandung kedekatan (uns), yang melalui al-Qur'an diungkapkan bahwa "Dan Kami lebih dekat kepadanya daripada urat lehernya sendiri” (QS. Qāf, 50:16). Pada tingkat pengalaman mistik ini, seorang pencinta menjadi tidak berjarak lagi dengan yang dicintainya, sifatsifat hamba akan menauladani sifat-sifat Allah. Bahkan, Allah akan menjadi seluruh indranya, sebagaimana diungkap dalam hadis qudsi berikut ini :

"Hamba-Ku mendekati-Ku dengan amalan-amalan ibadah yang lebih Kucintai sehingga Kutetapkan sebagai kewajiban atas dirinya. Dan hamba-Ku terus mendekati-Ku melalui amalan-amalan sunnah hingga Aku mencintainya; dan jika Aku telah mencintainya, Aku menjadi telinganya yang dengannya dia mendengar, matanya yang dengannya dia melihat, tangannya yang dengannya dia memegang, dan kakinya yang dengannya dia berjalan. Dan jika dia meminta (sesuatu) kepada$\mathrm{Ku}, \mathrm{Aku}$ memberikannya kepadanya. Jika dia benar-benar mencari pertolongan-Ku, Aku akan menolongnya". ${ }^{11}$

Kedua, dalam tingkat pengalaman mistik demikian pula, sifatsifat Allah mencurah kepada penempuh jalan mistik (sālik) yang

${ }^{10}$ Seyyed Hossein Nasr (Ed.), Ensiklopedi Tematis : Spiritualitas Islam (Fondasi) (Bandung : Mizan, 2002), hlm. 145.

${ }^{11}$ Via ibid., hlm. 147. 
berupaya keras mendekati-Nya agar menjadi kekasih-Nya. Di antara sifat Allah itu yang dikenal adalah 99 Nama Indah Allah (al-asmä' albusna), dan dapat diidentifikasi bahwa Allah lebih mengenalkan Diri sebagai Yang Mahapengasih (al-Raḥmān) dan Mahapenyayang (alRahiım) daripada Yang Mahamurka. Sifat Pengasih dan Penyayang yang feminin itu oleh Sachiko Murata disejajarkan dengan konsep “yin” dalam mistisisme China, sebaliknya konsep maskulin ia sejajarkan dengan konsep "yang".

Dengan pemahaman itu tidak berarti Tuhan selalu mencitrakan diri melalui sifat Pengasih dan Penyayang-Nya (feminin) saja, melainkan bersifat timbal-balik. Tatkala pelaku sufi sebagai makhluk-Nya yang berupaya menjalankan seluruh aturan-Nya (syariat) yang bersumber dari al-Qur'an dan hadis, melalui jalan sufi yang harus dilalui (tarekat) sehingga memiliki tujuan utama dari pencariannya (hakikat) yakni demi mengenal Allah dengan cara yang sebenar-benarnya (makrifat), maka dalam keadaan ini pelaku sufi bertindak secara maskulin untuk mencari cinta Allah, sedangkan Allah "diposisikan" secara feminin. Begitu halnya di saat Allah mencurahkan kasih-sayang-Nya, Allah bertindak secara feminin. Sebaliknya, tatkala hubungan itu dalam konteks pembalasan Allah disebabkan kemungkaran manusia, maka Allah bertindak secara maskulin. Namun demikian, menurut hadis terkenal mengenai singasana Allah (al-'arsh) tertulis, "Sesungguhnya, kasihsayang-Ku melampaui kemurkaan-Ku” (inna rahmati sabaqat ghadabi). Di dalam al-Qur'an pun lebih sering diulang-ulang nama yang menunjukkan sifat kasih-sayang Allah seperti al-Rahmōn, al-Rahim, alGhafür (Yang Mahapengampun), dibandingkan penyebutan nama-nama yang lain. Bahkan, setiap surah dalam al-Qur'an (kecuali satu surah saja) selalu diawali dengan nama Allah Yang Mahapengasih (al-Raḥmān) dan Mahapenyayang (al-Raḥim), dan bukan nama Allah yang menunjukkan kemahakuasaan. Al-Qur'an sendiri juga menyatakan bahwa al-Raḥmān merupakan hakikat Allah, "Serulah Allah atau serulah al-Raḥmān" (QS. al-Isrā,, 17 : 110).

Sementara itu, hubungan sufi (sebagai "pencari cinta" dalam hal ini berperspektif maskulin) dengan Yang Maha Dicinta yakni Allah (yang memperlihatkan aspek feminin), hal ini merupakan pencitraan kerinduan untuk bertemu Allah, yang pencarian alamat-Nya dengan 
merenungi ayat-ayat kauniyah-Nya pada manusia dan alam semesta (QS. al-Isrā', 17:44) sebab "Kemana pun engkau menghadap, di situlah wajah Allah" (QS. al-Baqarah, 2: 115). Oleh para sufi, pengenalan terhadap Allah melalui pemaknaan Nama dan Sifat-Nya itu diacukan pada sebuah hadis tentang "dicintakannya" Nabi Muhammad terhadap : "Tiga hal yang dicintakan kepadaku di dunia ini dari duniamu; wanitawanita, wewangian, dan penyenang mataku ada pada shalat". ${ }^{12}$ Menurut para sufi dengan merujuk pada hadis qudsi pula bahwa Allah melalui cinta-Nya ingin dikenal, karenanya Allah menciptakan makhluk: "Aku adalah perbendaharaan yang tersembunyi dan Aku ingin dikenal, karena itu Aku ciptakan manusia dan alam semesta". ${ }^{13}$ Padahal, sebaik-baik ciptaan Allah adalah manusia (QS. al-Tin, 95: 4), sedangkan manusia yang paling mencerminkan eksistensi Allah adalah wanita. Hal itulah yang menjadi jawaban terhadap misteri dari ungkapan hadis Nabi tentang hubungan antara kecintaannya terhadap wanita, wewangian, dan shalat. Mengapa demikian? Ibn Arabi melalui bukunya Fusus alHikam menjelaskan bahwa :

Ketika pria menatap (shahada) Realitas pada wanita, dia melihatNya pada suatu aspek pasif (munfa'át), sedangkan ketika dia menatapNya pada dirinya sendiri, sebagai makhluk di mana wanita terwujudkan darinya, dia melihat-Nya sebagai suatu aspek aktif ( $\left.f^{-}{ }^{\prime} i\right)$. Namun, ketika dia melihat-Nya pada dirinya sendiri, tanpa beberapa hal atas apa yang berasal darinya, dia melihat-Nya sebagai pasif pada Diri-Nya secara langsung. Bagaimanapun, penatapannya akan Realitas pada wanita lebih lengkap dan sempurna karena dalam cara ini dia menatap Allah dalam cara yang aktif dan pasif, sedangkan menatap Realitas hanya pada dirinya sendiri, dia melihat-Nya pada suatu cara yang terutama sekali pasif.

Maka penyaksiannya atas yang Nyata dalam diri wanita adalah yang paling lengkap dan paling sempurna sebab dia menyaksikan yang Nyata dalam kaitannya dengan kenyataan bahwa Dia sekaligus seorang wakil dan lokus penerima aktivitas. Tuhan mengungkapkan diri-Nya

${ }^{12}$ Via Ibn Arabi, Fusus al-Hikam, terj. Ahmad Sahidah dan Nurjannah Arianti (Yogyakarta: Pustaka Sufi, 2004), hlm. 397.

${ }^{13}$ Ibid., hlm. 490. 
dengan cara yang paling lengkap. ${ }^{14}$

Pencitraan erotik dalam puisi karya sufi sebagai ungkapan paling mewakili pengalaman mistik ini jelas dipengaruhi oleh gagasan Ibn Arabi tentang penyaksian Tuhan yang paling sempurna melalui "diri" wanita tersebut. Gagasan itu dijelaskan oleh al-Kashāni bahwa melalui pernikahan, "penyaksian yang Nyata dalam hubungan seksual adalah yang paling sempurna." "15 Al-Qaysari juga memberi penjelasan pandangan Ibn Arabi itu sebagai berikut :

Ketika dia menyaksikan-Nya dalam jiwanya sendiri tanpa mengingat bentuk wanita itu, dia menyaksikan-Nya sebagai suatu lokus yang menerima aktivitas, sebab dia adalah salah satu benda yang merupakan objek aktivitas Tuhan dan ciptaan-Nya.

Inilah sebabnya mengapa Nabi mencintai kaum wanita dikarenakan kesempurnaan penyaksian yang Nyata di dalam diri mereka. Sebab, yang nyata tidak pernah dapat disaksikan terlepas dari materi sebab Tuhan dalam esensi-Nya tidak tergantung pada semua dunia. Karena situasinya mustahil dalam kaitan ini, dan penyaksian berlangsung hanya dalam beberapa materi, maka penyaksian atas yang Nyata dalam diri kaum wanita merupakan penyaksian yang terbesar dan paling sempurna. ${ }^{16}$

Namun demikian, memaknai gagasan Ibn Arabi tersebut sekaligus diingatkan oleh Sachiko Murata bahwa jangan dibayangkan Ibn Arabi tengah menetapkan aktivitas seksual sebagai suatu cara untuk mencapai realitas ruhani. Ibn Arabi hanya menyarankan hal yang sama dengan yang dilakukan oleh Nabi Muhammad tatkala beliau berkata bahwa "Pernikahan adalah separuh dari agama". ${ }^{17}$ Sebaliknya, Ibn Arabi sedang menggambarkan bahwa kesempurnaan manusia hanya bisa dicapai oleh para kekasih Tuhan (awliya $\bar{a}$ ) dan para Nabi. Oleh sebab itu, bentuk penyaksian Tuhan semacam itu tidak mungkin dapat dilakukan oleh kebanyakan orang sebab sudah dikemukan oleh Ibn Arabi dalam bukunya Futühat al-Makekiyya bahwa "Kebanyakan orang adalah 'manusia-hewan' (al-insān al-ḥayawān)".

\footnotetext{
${ }^{14}$ Ibn Arabi, Fusus, hlm. 401.

${ }^{15}$ Via Sachiko Murata, The Tao of Islam (Bandung: Mizan, 1996), hlm. 256-257.

${ }^{16} \mathrm{I}$ bid., hlm. 257.

${ }^{17}$ Ibid., hlm. 259.
} 
Abdul Wachid B.S.

Ketika seorang mencintai kaum wanita di dalam batas-batas ini, itulah cinta ilahi. Namun, ketika seseorang mencintai mereka hanya dikarenakan nafsu alamiah, maka dia tidak memiliki pengetahuan tentang nafsu ini. Baginya suatu perkawinan menjadi bentuk tanpa ruh. Meskipun dalam kenyataan bentuk itu memiliki suatu ruh, hal itu tidak disaksikan oleh seseorang yang mendatangi istrinya semata-mata untuk menikmati kesenangan, namun tidak mengetahui dalam diri siapa. Dia tidak mengenal jiwanya sendiri.... Orang semacam itu suka menikmati kesenangan, maka dia mencintai lokus yang terdapat di dalamnya, yaitu wanita. Bagaimanapun juga ruh tersebut tetap tersembunyi darinya. Seandainya dia ingin mengetahuinya, dia akan mengetahui dalam diri siapa dia mendapatkan kesenangan dan siapa yang mendapatkan kesenangan, maka dia akan menjadi sempurna. ${ }^{18}$

Di dalam Fusus al-Hikam, ${ }^{19}$ Ibn Arabi menjelaskan hubungan lelaki, wanita, dan Tuhan, bahwa lelaki diciptakan oleh Allah melalui aspek femininitas Tuhan, sedangkan wanita diciptakan oleh Allah dari bagian lelaki. Dari itu, kecintaan lelaki terhadap wanita dan sebaliknya adalah merupakan penyatuan dari yang semula satu menjadi dua, dan kembali menjadi satu, menyatu dalam hakikat cinta Ilahi sebagaimana hal ini terjadi di dalam perkawinan suci manusia. Penyatuan lelaki dan wanita dalam perkawinan suci ini, menurut Ibn Arabi, bukan sematamata demi reproduksi dengan munculnya anak-anak manusia, melainkan demi perkawinan itu sendiri yang mendatangkan kenikmatan-kenikmatan pengalaman lelaki dan wanita yang amat mistikal, yang hakikatnya Ilahiah. Pada saat penyatuan dalam perkawinan itu, lelaki dan wanita menemu pengalaman mistik yang menyaingi nikmatnya penyatuan dengan Tuhan, dan karenanya Tuhan menuntutnya dengan menggantinya melakukan bersuci (taharah) yakni mandi jinābah. Melalui pemahaman tersebut, pengalaman mistik yang merupakan kerinduan dan penyatuan hamba dengan Tuhannya paling sempurna terefleksikan melalui aspek femininitas Tuhan, dan hal itu paling sempurna direnungi melalui penciptaan manusia, terutama pada wanita.

\footnotetext{
${ }^{18}$ Ibid., hlm. 259-260.

${ }^{19}$ Ibn Arabi, Fusus, hlm. 400.
} 


\section{D. "Wanita adalah Seberkas Sinar Tuhan"}

Perspektif demikian juga diungkap dalam perpuisian Jalāl al-Din Rümi, sufi penyair terbesar yang dilahirkan di Afghanistan 1207, dan meninggal di Konya Turki 1270 M. Semasih kecil ia sudah diramal oleh sufi penyair Farìd al-Dìn Attār bahwa Rūmì akan menyalakan antusiasme ketuhanan ke seluruh penjuru dunia. Memang, Rūmì kemudian dikenal secara luas sebagai pendiri tarekat Maulawiyah, yang salah satu ritualnya menari berputar-putar seperti gasing. Refleksi pengalaman mistiknya itu oleh Rümi ditulis dalam karya besarnya yakni Diwān Shamsi Tabriz, fih mā fih, dan Mathnāwi.

Di dalam puisinya Rūmì menyatakan kerinduan kepada Allah melalui pencitraan-pencitraan feminin. Bahkan, makna sebagian puisinya ditentukan oleh persepsi dimensi kewanitaan dalam tasawuf itu sebab menurut Rūmi, "Wanita adalah seberkas sinar Tuhan." Hal itu sebab Allah lebih mencitrakan Diri melalui sifat feminin, Pengasih (al-Raḥmān) dan Penyayang-Nya (al-Raḥim). Di samping itu, mengenaliNya akan dapat dipahami melalui ciptaan-Nya, dan yang tampak paling sempurna melalui diri wanita sebab "dia berdaya cipta," ungkap Rūmi dalam sajaknya, selengkapnya berikut ini: ${ }^{20}$

\section{Cinta Wanita}

Jika secara lahir istrimu yang kauatur, secara batin kaulah yang diatur oleh ia yang kauinginkan.

Inilah ciri manusia: pada jenis binatang lain cinta kurang terdapat, dan ia menunjukkan derajat mereka.

Nabi berkata bahwa wanita mengungguli orang bijak, sementara lelakilelaki sesat mengunggulinya.

Sebab dalam diri lelaki melekat kekejian binatang.

Cinta dan kelembutan adalah sifat manusia, nafsu dan angkara adalah sifat binatang.

Wanita adalah seberkas sinar Tuhan: ia bukan kekasih lelaki yang duniawi. Ia suka mencipta: mungkin kau yang berpendapat bahwa ia bukan ciptaan.

${ }^{20}$ Abdul Hadi W.M. (penerjemah), Sastra Sufi (Jakarta: Pustaka Firdaus, 1985), hlm. 13. 
Abdul Wachid B.S.

Dalam sajak Rūmìitu, diri wanita ditampilkan tidak sebagai molek tubuh, yang selalu dikelasduakan oleh kaum lelaki di tengah perilaku budaya patriarkhal, melainkan sebentuk makhluk yang tidak saja indah secara fisik namun sekaligus sebagai "seberkas sinar Tuhan". Karenanya, sudut-pandang tersebut jelas menuntut ditingkatkannya pemahaman tentang cinta, dengan jalan mengembalikannya pada hakikat semua cinta yakni Ilahiah. Mencintai dengan pemahaman demikian bukan hanya dikarenakan nafsu alamiah, melainkan memiliki pengetahuan tentang nafsu (nafs, jiwa). Oleh sebab itu, kata Rümi, "ia (wanita) bukan kekasih lelaki yang duniawi," atau dalam ungkapan Ibn Arabi, "yang hanya mendatangi istrinya semata-mata untuk menikmati kesenangan, namun tidak mengetahui dalam diri siapa." Jika demikian, "perkawinan hanya menjadi bentuk tanpa ruh. Meskipun dalam kenyataan bentuk itu memiliki suatu ruh," karenanya lelaki seperti itu "tidak mengenal jiwanya sendiri." Padahal, "Ia (wanita) suka mencipta" seperti halnya sifat Allah, karenanya wanita merupakan metafora yang paling sempurna bagi kehadiran-Nya di dunia ciptaan. Karenanya pula, pada tingkat pemaknaan spiritual yang paling tinggi, wanita dipandang "bukan sebagai ciptaan" oleh kaum sufi. Hal itu, menurut Ibn Arabi, ${ }^{21}$ sebab "dia menyaksikan yang Nyata dalam kaitannya dengan kenyataan bahwa Dia sekaligus seorang wakil dan lokus penerima aktivitas"; "maka penyaksian atas yang Nyata dalam diri kaum wanita merupakan penyaksian yang terbesar dan paling sempurna."

Pemikiran tersebut menjadi landasan filosofis erotisitas pencitraan cinta dalam perpuisian kaum sufi penyair, tak terkecuali karya sufi penyair legendaris di sepanjang sejarah sastra sufisme seperti Jalāl al-Din Rūmi, Manșūr al-Hallāj, maupun Rabíah al-Adawiyyah. Melalui pencitraan cinta lawan jenis kelamin yang begitu menakjubkan, ekstase percintaan bersama Yang Mahakekasih keindahannya dapat diungkapkan melalui bahasa puisi.

${ }^{21}$ Ibn Arabi, Fușus, hlm. 401. 


\section{E. Lukisan Peleburan Cinta yang Erotik: Sana'i, Rabi'ah al- Adawiyyah, Sa'di, Jami, dan Amir Hamzah}

Sebagaimana halnya Sana'i, sufi penyair yang karya terkenalnya ialah Haqiqat al-Haqa’iq (Taman Kebenaran), dengan kemesraan yang dalam melukiskan saat-saat yang pedih setelah bersatunya dengan Yang Maha Kekasih, maka kerinduan itu, "Semua itu menyiksa hatiku," ungkap guru dari sufi penyair Farỉd al-Din Attār ini dalam sajaknya. Sekalipun demikian, sufi yang dilahirkan di Ghazna pada tahun 1046, dan meninggal pada tahun 1131, ini pun tetap bertegar dalam upaya bertemu untuk menyatu dengan Yang Maha Kekasih. Ungkapan sajak tersebut dikutip selengkapnya berikut ini. ${ }^{22}$

\section{Selamat Malam}

Kekasih, kulimpahkan hatiku padamu -

Selamat malam! Aku pergi.

Kau tahu keharuan hatiku yang dalam -

Selamat malam! Aku pergi.

Apa aku tak bisa melihatmu lagi?

Sungguh? Sungguh?

Kudekap jam-jam Perpisahan erat-erat -

Selamat malam! Aku pergi.

Rambutmu yang nanar dan wajah berseri

Menawan dan menjerat

Membuat hari-hariku kelam dan muram

Selamat malam! Aku pergi.

O, Wajahmu adalah Cahaya Iman, rambutmu

Seperti kebingungan yang sangsi :

Semua ini menyiksa hatiku -

Selamat malam! Aku pergi.

Aku berdiri di antara api dan air

Kau lihat aku

Bibirku pecah dan kering, mataku berurai airmata :

Selamat malam! Aku pergi.

Pencitraan serupa sajak Sana'i tersebut banyak kita jumpai dalam puisi yang ditulis oleh para sufi untuk menggambarkan kerinduan dan

${ }^{22}$ Abdul Hadi W.M. (penerjemah), Sastra., hlm. 55-56. 
kemabukan cinta dalam keadaan ekstase (wajd). Sajak Sana’i tersebut melukiskan bagaimana saat malam hampir berakhir di ujung pagi sehingga seorang pencinta merasa sangat berat meninggalkan pertemuannya dengan Tuhan ("Kekasihku”), yang dicitrakan sebagaimana kekasih fisik perempuan dengan "/Rambutmu yang nanar dan wajah berseri/ Menawan dan menjerat/. Namun, pencitraan fisik perempuan itu pada akhirnya diposisikan sebagai penanda saja dari sebuah pengetahuan tentang kehadiran Allah ('ilm al-hudüri) melalui tahajud cinta seorang hamba. Hal itu dikatakan oleh Sana'i sebab "Wajahmu adalah Cahaya Iman" sehingga menyerap kedirian "aku" sehingga "Aku berdiri di antara api dan air", yang dapat dimaknakan sebagai di antara hasrat yang berkobar disebabkan oleh api cinta sekaligus terpenuhinya dahaga kalbu disebabkan meminum air cinta itu sendiri. Segala kemabukan itu memiliki fungsi memberi gambaran bahwa betapa pertemuan dengan Tuhan merupakan birahi yang ilahiah ('áshiq), suatu gambaran mesra yang dekat dengan pemahaman kebirahian manusia saat merasakan cinta terhadap lawan jenisnya sebab hal itulah puncak pengalaman keindahan yang pernah dialami oleh manusia di dunia. Demikian pula, mabuk cinta kepada Allah ini, menurut Sangidu, 23 "merupakan keadaan yang tidak dapat dihindari oleh para sufi yang telah merasakan nikmatnya mengenal dan bertemu Allah Ta'ala".

Kenikmatan pertemuan antara sufi dan Allah itu tidak dapat dilukiskan dengan kata-kata biasa, karenanya para sufi menggunakan ungkapan-ungkapan tamsil dan metafora agar mabuk cinta kepada Allah itu bisa diungkapkan. Karena pengalaman cinta yang paling maksimal yang pernah dialami manusia adalah penyatuan lelaki dan perempuan dalam bercinta, maka pencitraan cinta erotik itu dijadikan perbandingan untuk menggambarkan nikmatnya bercinta dengan Allah.

Alasan psikologis yang Freudian terhadap kecenderungan manusia itu, tentu saja dalam pemikiran sufisme tidaklah cukup berhenti di situ. Akan tetapi, pencitraan cinta erotik sepasang kekasih

${ }^{23}$ Sangidu, Wachdatul Wujud: Polemik Pemikiran Sufistik antara Hamzah Fansuri dan Syamsuddin as-Sumatrani dengan Nurruddin ar-Raniri (Yogyakarta: Gama Media, 2003), hlm. 201. 
itu lebih didasarkan pada alasan memuliakan wanita sebagai ciptaan Allah, yang lebih merepresentasikan kesempurnaan sebagai tanda (ayat kauniyah) keindahan Allah dibanding ciptaan-Nya yang lain, sebagaimana hal ini dinyatakan oleh Ibn Arabi.

Ungkapan-ungkapan mabuk cinta, bahkan ajaran cinta dalam tasawuf ("ishq, mạ̣abbah) ini dipopularkan oleh wanita sufi penyair Rabi'ah al-Adawiyyah (dilahirkan di Basrah Irak tahun 714 M, dan meninggal tahun $801 \mathrm{M}$ ). Pencitraan cinta erotik dalam puisi Rabíah lebih memetaforakan Tuhan sebagai maskulin sebagaimana ungkapan ini : "O penawar jiwaku, hatiku/ Adalah santapan yang tersaji bagi mau-Nya/ Barulah jiwaku pulih jika telah bersatu dengan-Mu/".

Namun demikian, Tuhan tetaplah dikenali Rabi'ah sebagai "Kekasih" yang "Cinta-Nya padaku tak pernah berbagi"; Tuhan merengkuh dengan sifat femininitas-Nya sebagai Yang Maha Pencipta Keindahan (al-Bādi') dalam ungkapan "Kapan dapat kurenungi keindahan-Nya"; juga sebagai Yang Mahaasih (al-Ra'üf) dan Yang Maha Mengasihi (al-Wadūd) dalam ungkapan "O Sukacita dan Nyawaku, moga kekallah/ Jiwaku. Kaulah sumber hidupku/ Dan dari-Mu jua birahiku berasal/". Ungkapan-ungkapan yang mencitrakan Tuhan sebagai "Kekasih" itu tiada lain sebagai perluasan dari sifat femininitas Tuhan (Maha Pengasih/al-Rạ̣mān, Maha Penyayang/al-Raḥim). Ungkapan terhadap "Kekasih" itu jelas sekali mencitrakan cinta erotik, dan tujuan akhir dari erotisitas ungkapan bahwa "/Hasratku adalah bersatu dengan-Mu/ melabuhkan rindu”, yakni cinta dan rindu sebagai hasrat kedekatan (uns). Sajak Rabi'ah al-Adawiyyah dikutip selengkapnya berikut ini. ${ }^{24}$

\section{Tenteram}

Hatiku tenteram dan damai jika aku diam sendiri

Ketika Kekasih bersamaku

Cinta-Nya padaku tak pernah berbagi

Dan dengan benda yang fana selalu mengujiku

Kapan dapat kurenungi keindahan-Nya

Dia akan menjadi mihrabku

Dan arah-Nya menjadi kiblatku

${ }^{24}$ Abdul Hadi W.M. (penerjemah), Sastra, hlm. 65. 
Abdul Wachid B.S.

Bila kumati karena cinta, sebelum terpuaskan

Akan tersiksa dan lukalah aku di dunia ini

$\mathrm{O}$ penawar jiwaku, hatiku

Adalah santapan yang tersaji bagi mau-Nya

Barulah jiwaku pulih jika telah bersatu dengan-Mu

O Sukacita dan Nyawaku, moga kekallah

Jiwaku. Kaulah sumber hidupku

Dan dari-Mu jua birahiku berasal

Dari semua benda di dunia ini

Diriku telah tercerai

Hasratku adalah bersatu dengan-Mu

Melabuhkan rindu.

Yang dimaksudkan Rabi'ah dengan ungkapan "Hasratku adalah bersatu dengan-Mu/ Melabuhkan rindu" bahwa seorang pencinta (mubibb) hanyut dalam ketiadaan dan hilang diri (fanā'), menyatukan diri dengan Tuhan dan menjadi milik Tuhan. Hal itu merupakan perluasan dari ayat al-Qur'an bahwa 'Tuhan mencintai mereka dan mereka mencintai-Nya" (5:59), bahkan "Mereka yang beriman hanyut di dalam cinta mereka kepada Allah Swt” (2:165).

Ungkapan "hanyut" atau "karam" cinta juga digali melalui pencitraan cinta erotik oleh sufi penyair Sa'di dalam sajaknya. "Dalam semua aku hapus," ungkapnya sebab puncak dari cinta (mạ̣abbah) tiada lain adalah penghapusan total terhadap sifat-sifat aku-manusia dengan menggantikannya dengan sifat-sifat Aku-Allah. Namun demikian, berbeda dengan sufi lainnya, penggantian sifat aku-manusia dengan sifat Aku-Allah itu oleh Sa'di diimplementasikan di dalam kehidupan sosial, ia tidak hanya menjalani kehidupan asketik. Sa'di dilahirkan tahun 1184 M, dan meninggal dunia pada tahun 1292 M. Karyanya yang paling berpengaruh pada kesusastraan dunia adalah Gulistan dan Bustan. Menurut Emerson ${ }^{25}$ bahwa kedua karyanya itu berpengaruh pada kesusastraan Jerman. Di antara sajak Sa'di yang menarik itu dikutip selengkapnya berikut ini. ${ }^{26}$

\footnotetext{
${ }^{25}$ Abdul Hadi W.M. (penerjemah), Sastra, hlm. 296.

${ }^{26}$ Abdul Hadi W.M. (penerjemah), Sastra, hlm. 136.
} 


\section{Karam}

Mataku membanjir rinduku kehendaknya

Hatiku membakar di api nafsunya

Dalam semua aku hapus

Dalam banjir karam dalam api hangus.

Dengan Sa'di mengungkapkan bahwa "Mataku membanjir rinduku kehendaknya", sesungguhnya setiap ungkapan kerinduan dan cinta mistik itu adalah manifestasi dari mengingat (dhikr) kepada Tuhan. Penyebutan "Kekasih" yang berulang-ulang dalam puisi sufi pun tiada lain sebagai cara mengingat (dhikir), memikirkan (fikr), dan merenung (mushähadah) terhadap "Wajah" Kekasih Yang Mahaindah. Pada saatnya Kekasih menyingkapkan keindahan wajah-Nya, maka pada saat itu puisi oleh sufi difungsikan sebagai tempat menyatakan kemabukan (shawq) dan penyatuan cinta (fanà). Hal senada juga diungkapkan oleh Abdul Hadi W.M. ${ }^{27}$ bahwa puisi dipandang sebagai proyeksi dzikir dan ekspresi kerinduan, sedangkan keindahan yang dihadirkan melalui puisi dimaksudkan agar dapat menerbitkan keadaan-keadaan ruhani yang diperlukan oleh pembaca dalam mencapai mushähadah. Mushāhadah, menurut al-Ghazali ialah kesanggupan merenungi keindahan Yang Haqq melalui makrifat. ${ }^{28}$

Oleh karenanya, sangatlah tepat gambaran tentang seorang pencinta ('áshiq) yang sedang mengalami kegairahan mistik (wajd) kepada Kekasihnya di dalam puisi karya Jami, seorang sufi penyair yang lahir tahun 1414 M, dan meninggal tahun 1492 M. Jami dipandang oleh Abdul Hadi W.M. ${ }^{29}$ sebagai penyair besar terakhir Parsia klasik, seorang sufi yang keilmuan Islamnya luas sehingga mampu menulis tentang berbagai hal, dan karyanya mempengaruhi kesusastraan Prancis.

Sajak "Denganmu" karya Jami ${ }^{30}$ dan sajak "Kau dan Aku" karya Jalāl al-Dỉn Rümí ${ }^{31}$ berikut juga menggambarkan kegairahan cinta melalui pencitraan cinta erotik.

${ }^{27}$ Abdul Hadi W.M., Tasawuf, hlm. 69.

${ }^{28}$ Ibid., hlm. 72.

${ }^{29}$ Abdul Hadi W.M. (penerjemah), Sastra, hlm. 293.

${ }^{30}$ Ibid., hlm.168.

${ }^{31}$ Sapardi Djoko Damono (penerjemah), Jalaluddin Rumi Sufi Penyair Terbesar (Jakarta: Pustaka Firdaus, 1986), hlm. 57. 
Abdul Wachid B.S.

\section{Denganmu}

Orang meletakkan jemarinya pada kening indahmu

Dan berseru : "Lihat, bulan purnama ada di sini!"

Janji fajar kemilau kalbu yang diberkahi

Berpijar di wajahmu menulari para pencintamu

Pesta suci hanya setahun sekali

Namun setiap hari denganmu aku pergi ke pesta

Dan dari pipimu kutahu betapa meriah pesta itu

Walau tak seorang pun muncul di sana

Bila kau berkata : "Dengan siksa derita kubunuh jiwamu!"

Bagiku pembunuhan itu adalah sebuah perayaan

Penjahit Waktu, ukurlah tinggi badanmu

Potonglah jubah karunia yang tak terperikan itu

Namun, o Jami, pawai yang menyenangkan itu

Jika tak bersama-Nya adalah derita yang begitu menyiksa

\section{Kau dan Aku}

Bahagia saat kita duduk di pendapa, kau dan aku.

Dua sosok dua tubuh namun hanya satu jiwa, kau dan aku.

Harum semak dan nyanyi burung menebarkan kehidupan

Pada saat kita memasuki taman, kau dan aku.

Bintang-bintang yang beredar sengaja menatap kita lama-lama;

Bagai bulan kita bagikan cahaya terang bagi mereka.

Kau dan aku, yang tak terpisahkan lagi,

menyatu dalam nikmat tertinggi,

Bebas dari cakap orang, kau dan aku.

Semua burung yang terbang di langit mengidap iri

Lantaran kita tertawa-tawa riang sekali, kau dan aku.

Sungguh ajaib, kau dan aku, yang duduk bersama di sudut rahasia,

Pada saat yang sama berada di Iraq dan Khorastan, kau dan aku.

Dari kedua sajak itu, terutama sajak Rūmi tergambarkan penyatuan sepasang kekasih di dalam percintaan profan, yang dilatari oleh keindahan taman, suatu pencitraan cinta erotik seperti ungkapan ini, "Kau dan aku, yang tak terpisahkan lagi,/ menyatu dalam nikmat tertinggi,/". Akan tetapi, maksud Rūmi tak sebatas menggambarkan keindahan sepasang kekasih yang sedang bercinta di suatu taman. Keindahan semacam itu oleh al-Jilli disebutnya sebagai keindahan-luar 
(ḅusn) dari puisi. Keindahan-luar atau keindahan-lahir dari puisi disebut sürah, yang berarti gambar, contoh atau salinan, yakni salinan dari makna yang berada di dalamnya. ${ }^{32}$ Hal ini berarti jika seorang pembaca hanya terikat pada keindahan-luar dari puisi, karenanya ia akan terjebak pada yang tersurat belaka, tanpa mampu membaca makna yang tersirat di dalam puisi yang justru merupakan hakikat atau "isi" dari puisi tersebut.

Tentang wawasan estetik sufi berkenaan dengan puisi, Abdul Hadi W.M. ${ }^{33}$ menyatakan bahwa :

Puisi adalah sebuah bangunan kejiwaan dalam wujud bahasa yang pengucapannya tidak langsung dan strukturnya unik. Dalam wawasan estetik sufi bahasa puisi hanya dapat wujud apabila terdapat makna yang hendak dicetakkan ke dalam sebuah struktur pengucapan yang bernama bahasa atau komposisi puitik. Jika tidak ada makna, sebuah puisi hanya merupakan susunan bahasa yang tidak berjiwa. Makna adalah keindahan sisi dalam dari sebuah puisi. Wilayah makna adalah pengalaman atau keadaan ruhani seorang penyair.

Dalam hal ini, sebagaimana para sufi penyair lain, Rūmì pun menekankan pada makna yang tersirat dalam puisi itu, yakni keindahandalam (jamāl). Rümi tidak bermaksud menggambarkan percintaan erotik belaka, gambaran sepasang kekasih yang sedang asyik-mansyuk itu hanyalah tamsil dari kemabukan kalbu seorang pencinta ('áshiq) yang sedang mengalami kegairahan mistik (wajd) dan fana di dalam jiwa Yang Maha Kekasih sehingga merasakan puncak nikmat dari persatuan tersebut. Dari sajak semacam sajak Jami dan sajak Rūmi itu tergambar hubungan antara keindahan-lahir dan keindahan-batin. Hal tersebut merupakan perluasan makna dari pernyataan al-Qur'an bahwa mengenal Allah adalah mengenal "Yang Lahir dan Yang Batin" (QS., 57:3), mengenal "Ayat-ayat-Nya terbentang di alam semesta dan dalam diri manusia" (QS., 41:53), dan oleh karena itu "Kemana pun kau memandang akan terlihat wajah-Nya" (QS., 2:115).

Puisi dalam konsepsi sufisme pun merupakan gambaran dari kebertautan antara yang tersurat dan yang tersirat itu, antara yang lahir dan yang batin; antara keindahan-luar pada ungkapan-ungkapan bahasa,

\footnotetext{
${ }^{32}$ Abdul Hadi W.M. (penerjemah), Sastra, hlm. 76.

${ }^{33}$ Ibid.
} 
dan keindahan-dalam pada kandungan hikmahnya yaitu tentang pengetahuan tentang hakikat kehidupan.

Menurut Braginsky ${ }^{34}$ bahwa dalam puisi, hikmah memperkaya batin pembaca. Selanjutnya, Abdul Hadi W.M. menguraikan pandangan Braginsky tersebut bahwa: ${ }^{35}$

Karena sifatnya yang tak terbatas dan universal, serta dapat memperkaya batin itulah para penulis sufi lebih mengutamakan jamäl dibandingkan dengan busn, tanpa mengecilkan peran busn. Dalam puisi keindahan batin melahirkan makna. Maknalah yang merupakan struktur batin puisi. Sedang keindahan luar melahirkan surah, yaitu bentuk yang ada di luarnya. Sürah adalah wakil makna di alam penampakan dan kehadirannya sepenuhnya ditentukan oleh makna. Sürah merupakan struktur fisik sebuah puisi.

Dengan begitu, penampakan melalui ungkapan pencitraanpencitraan cinta erotik dalam puisi sufi itu masih perlu diburu pemaknaannya dengan mencari rujukannya (hipogram), yang hal itu sebagaimana sudah diuraikan di depan, yakni jelas berkaitan dengan pandangan dunia kaum sufi terhadap hubungan antara makhluk (alam dan manusia) dan Tuhan. Oleh sebab itu, "perbandingan" melalui pencitraan cinta erotik merupakan hal yang vital dalam perpuisian sufi sebab dengan cara itu dapat memberi ungkapan puitik halus dan penuh nuansa estetik; dapat mudah meresap dan berkesan dalam hati pembaca; dan para sufi dapat melindungi rahasia perjalanan ruhani mereka dari pengetahuan orang biasa. Di samping itu, dengan menggunakan citracitra simbolik erotik para sufi sekaligus memberi gambaran kedekatannya dengan Tuhan, dan bahwa betapa manusia merupakan penyaksian citra Tuhan yang paling lengkap dan sempurna, terutama pada diri wanita, sebagaimana pandangan Ibnu Arabi.

"Perbandingan" Tuhan dengan "Kekasihku" juga secara estetik dan imajinatif digambarkan dalam perpuisian Amir Hamzah, terutama sekali dalam sajak berjudul "Doa" 36 dan "Padamu Jua". ${ }^{37}$ Dengan perbandingan serupa itu, gagasan tentang sifat Tuhan yang feminin, Yang Raḥmān dan Yang Raḥim, yang penyaksian-Nya lebih terepresentasi

\footnotetext{
${ }^{34}$ Ibid., hlm. 77.

${ }^{35}$ Ibid.

${ }^{36}$ Amir Hamzah, Nyanyi Sunyi (Jakarta: Dian Rakyat, cet.x, 1985), hlm. 15.

${ }^{37}$ Ibid., hlm. 5 .
} 
melalui diri wanita, menjadi lebih dapat dirasakan oleh pembaca. Amir Hamzah digelari oleh HB. Jassin sebagai "Raja Penyair Pujangga Baru”. Ia dilahirkan tahun 1911, dan meninggal tahun 1941 sebagai korban revolusi, yang dibunuh oleh sekelompok pemuda komunis ketika Amir Hamzah menjabat sebagai Bupati Langkat. Sajak-sajaknya dibukukan dalam Buab Rindu, dan Nyanyi Sunyi, dan dinilai oleh banyak kalangan sebagai dipengaruhi oleh Hamzah Fansuri (seorang sufi penyair yang hidup di Barus, Aceh, antara pertengahan abad ke-16 dan perempat awal abad ke-17). Di antara sajak Amir Hamzah itu dikutip selengkapnya berikut ini.

\section{Doa}

Dengan apakah kubandingkan pertemuan kita, kekasihku?

Dengan senja samar sepoi, pada masa purnama meningkat naik, setelah menghalaukan panas payah terik.

Angin malam menghembus lemah, menyejuk badan, melambung rasa menayang pikir, membawa angan ke bawah kursimu.

Hatiku terang menerima katamu, bagai bintang memasang lilinnya.

Kalbuku terbuka menunggu kasihmu, bagai sedap malam menyirak kelopak.

Aduh, kekasih, isi hatiku dengan katamu, penuhi dadaku dengan cahayamu, biar bersinar mataku sendu, biar berbinar gelakku rayu!

\section{F. Penutup}

Semua sajak karya sufi penyair yang dicontohkan merepresentasikan posisi pentingnya Tuhan sebagai "Kekasih", dan pencitraan peleburan cinta melalui pencitraan cinta lawan jenis begitu pentingnya sebab aktivitas cinta tersebut merupakan gambaran paling mewakili dari kebersamaan cinta yang dapat dikenali oleh manusia. Hal itu juga merupakan tamsil yang mengejawantahkan "penampakan" eksistensi Tuhan melalui alam shahädah. Oleh karenanya, simbol atau misal, perumpamaan atau tamsil, analogi atau kias dan metafora secara luas di dalam perpuisian sufisme menjadi penting untuk dimaknakan. Dengan demikian, sesungguhnya puisi sufi sebagaimana tasawuf itu 
Abdul Wachid B.S.

sendiri, yang menggambarkan hubungan keindahan Yang Mahasatu dengan keindahan objek yang bermacam-macam di alam shahädah. Dengan demikian pula, puisi sufi merupakan bentuk dari penyaksian (shahädah) dan perenungan (mushāhadah) akan keesaan Tuhan, tujuannya ialah menimbulkan pencerahan berupa kesadaran terhadap pengetahuan (makrifat) tentang diri dan Tuhan sehingga sampai kepada Cinta Ilahiyah (mahabbah). 


\section{BIBLIOGRAFI}

Arabi, Ibn, Fusus al-Hikam, terj. Ahmad Sahidah dan Nurjannah Arianti (Yogyakarta: Pustaka Sufi, 2004).

Damono, Sapardi Djoko, Jalaluddin Rumi Sufi Penyair Terbesar (Jakarta: Pustaka Firdaus, 1985).

Fromm, Erich, The Art of Loving (Jakarta : Fresh Book, 2002).

Hadi W.M., Abdul (penerjemah), Sastra Sufi (Jakarta: Pustaka Firdaus, 1985).

—, Tasawuf yang Tertindas (Jakarta: Paramadina, 2001).

Hamzah, Amir, Nyanyi Sunyi (Jakarta: Dian Rakyat, cet.x, 1985).

Murata, Sachiko, The Tao of Islam (Bandung: Mizan, 1996).

Nasr, Seyyed Hossein, Knowledge and the Sacred (New York: The Crossroad Publishing Company, 1981).

-, (ed.), Ensiklopedi Tematis: Spiritualitas Islam (Fondasi) (Bandung: Mizan, 2002).

Sangidu, Wachdatul Wujud: Polemik Pemikiran Sufistik antara Hamzah Fansuri dan Syamsuddin as-Sumatrani dengan Nurruddin ar-Raniri (Yogyakarta: Gama Media, 2003).

Schimmel, Annemarie, Dimensi Mistik dalam Islam, cet. ii (Jakarta: Pustaka Firdaus, 2003).

Wachid B.S., Abdul, Religiositas Alam: dari Surealisme ke Spiritualisme D. Zawawi Imron (Yogyakarta: Gama Media, 2002). 